\title{
A DEMOCRACIA E A LUTA POLÍTICO-JURÍDICA NO CAMPO BRASILEIRO
}

Thiago Lemos Possas ${ }^{1}$

Faculdade São Luís

\section{RESUMO}

Parte-se da realidade de violência e exploração que marca historicamente o campo brasileiro para apontar caminhos de tentativa de superação desse quadro. Destaca-se a luta pela reforma agrária como ponto de partida para a democratização das relações sociais no campo, tendo-se em vista que a mesma figura como momento inaugural de um processo incessante de participação política e distribuição de terras e poder no âmbito rural. A continuação da luta e formação de focos de resistência são fundamentais nesse processo. Adota-se, no presente artigo, o método dialético optando-se pelo procedimento crítico na tratativa da conformação democrática (ou sua ausência) no campo brasileiro.

Palavras-chave: concentração fundiária; democratização do campo; lutas sociais; reforma agrária.

1 Doutorado em Direito pela Universidade de São Paulo (USP). Mestrado em Direito Público pela Universidade Estadual Paulista (UNESP). Especialização em Direito Público pela UNIDERP/LFG. Graduado em Direito pela Universidade Federal de Minas Gerais (UFMG). Professor na Faculdade São Luís. ORCID: https://orcid.org/0000-0003-4070-7126 / e-mail: thiagolp84@yahoo.com.br 


\section{DEMOCRACY AND THE POLITICAL-JURIDICAL STRUGGLE IN THE BRAZILIAN COUNTRYSIDE}

\section{ABSTRACT}

It starts from the reality of violence and exploitation that historically marks the Brazilian countryside to point out ways of trying to overcome this situation. To stand out in the struggle for agrarian reform as a starting point for the democratization of social relations in the countryside, bearing in mind the same figure at the beginning of an incessant process of political participation and distribution of land and power in rural areas. The continuation of the struggle and the formation of foci of resistance are fundamental in this process. In this article, the dialectical method is adopted, opting for the critical procedure treated of democratic conformation (or its absence) in the Brazilian field.

Keywords: democratization of the countryside; land concentration; land reform; social struggles. 


\section{INTRODUÇÃO}

A questão da democracia no campo brasileiro é de fundamental importância, pois há empecilhos estruturais gravíssimos para sua implantação, como a violência, o uso de armas, a existência do latifúndio e da pobreza, mas, igualmente, há tradição de luta como parte da história do povo brasileiro. Os movimentos sociais rurais têm um histórico de aguerridas lutas e de mobilização política intensa, mesmo sofrendo com as mais variadas formas de violência. Se a democracia se fizer presente de modo a ser continuamente redefinida pelo povo do campo, todo esse potencial de mobilização e toda essa energia instituinte da população rural poderão se converter no elemento central para todo o desenvolvimento democrático posterior.

Entende-se que para se instaurar a democracia (ou o que se espera dela) na área rural é imprescindível que o elemento popular se faça presente, protagonizando essa construção. A reflexão aqui desenvolvida pretende fundamentar que a atuação intensa da população do campo, dentro e fora das instituições estatais, é o que poderá catalisar o processo de efetivação e de concretização de direitos já consagrados no plano formal.

E é nesse ponto que o Direito se vincula à questão democrática. Trata-se de demonstrar que essa imbricação entre o Direito e a democracia constitui uma alternativa mais interessante para que os direitos se tornem realidade, abandonando a caluniosa posição de meras ficções, que só existem nas abstratas previsões normativas. Para tanto, deve-se buscar subsídios na teoria democrática contemporânea, visando o alargamento do campo jurídico na luta por efetividade.

Fundar uma democracia substancial no âmbito rural contra a histórica violência e espoliação dos trabalhadores é passo imprescindível para a consolidação democrática do país como um todo.

\section{VIOLÊNCIA E DÉFICIT DEMOCRÁTICO NO CAMPO}

No Brasil, não há como falar em democratização deixando de lado a falta de democracia em âmbito rural. Isso impacta, evidentemente, a questão democrática do país como um todo. À violência das armas, que historicamente se voltou contra trabalhadores e militantes sociais, somam-se a violência da pobreza, da miséria, da ausência de possibilidade de vida digna e produtiva por meio da terra e da subsistência dela extraída, bem 
como a violência do latifúndio, que concentra o que deveria ser distribuído e desobedece à secular funcionalização da propriedade privada, deixando à míngua milhões de famílias que poderiam elevar a outro patamar a luta pela soberania alimentar do país.

Portanto, é importante pensar a Reforma Agrária como "[...] eixo central de um programa político democrático" (MANIGLIA, 2002). Para tanto, deve-se levar em consideração o contexto rural brasileiro, que se caracteriza, até hoje, por ser espaço de anomia e déficit democrático.

A realidade do campo é um entrave à "[...] concretização da democracia social e econômica, cujo pilar [na realidade do campo] é a arcaica estrutura fundiária, marcada pela grande concentração de terras, que desde os tempos coloniais acumula em paralelo a concentração da miséria e da desigualdade" (MANIGLIA, 2002). Portanto, falar da democracia no campo, hodiernamente, é falar também (e, talvez, principalmente) de sua ausência.

Abramovay e Morello (2010, p. 1, grifo do autor) destacam que a (relativa, diga-se) distribuição de renda operada no campo por meio dos programas de transferência de renda do governo federal é fato isolado, não sendo acompanhada de outros avanços, como no setor da saúde, do saneamento básico, e da educação. Os autores apontam a necessidade de mobilização democrática para que ocorra essa extensão:

\footnotetext{
Mas justamente por dependerem de mobilização democrática - e não de mecanismos indiretos, como, por exemplo, o crescimento econômico - que a redução da desigualdade não atinge simultaneamente todas as dimensões de que ela é composta. O sucesso na redução da pobreza e da desigualdade de renda, nem de longe é o mesmo daquele obtido em outros fatores como a educação, o saneamento e o próprio acesso à saúde. A extraordinária mobilização social que generalizou a aposentadoria no meio rural não teve equivalente, por exemplo, num movimento voltado a aprimorar a qualidade da educação.
}

Por exemplo, com relação à precariedade da educação em âmbito rural, em situação ainda pior que a educação nas cidades, destacam os autores (ABRAMOVAY; MORELLO, 2010, p. 5) que:

É verdade que o Brasil avançou muito quanto à frequência escolar, tanto no meio urbano como nas áreas rurais. No entanto, em 2000 nada menos que $72 \%$ das crianças do meio rural estavam atrasadas em sua escolarização, contra $50 \%$ dos que viviam em áreas urbanas. Apenas $12,9 \%$ dos jovens de 15 a 17 anos que habitavam as áreas rurais estavam matriculados no ensino médio, nível adequado a esta faixa etária. Para o Brasil urbano, a proporção era de 38,1\% em 2000. 
Além da educação, Abramovay e Morello (2010, p. 6) destacam que a

[...] mortalidade infantil, acesso a água encanada, saneamento básico, coleta domiciliar de lixo também são fatores em que os indicadores rurais são bem mais precários que os urbanos, embora os avanços num caso e no outro sejam nítidos durante a atual década.

Se isso já não bastasse para a configuração de uma absurda deficiência da atuação estatal no meio rural, há diversos outros fatores que emperram seu desenvolvimento democrático. O campo brasileiro é ainda marcado por diversas manifestações de violência contra sua população, como a violência da concentração de terras nos latifúndios, a repressão aos movimentos sociais que lutam legitimamente por direitos - estes, muitas vezes, já reconhecidos pelo ordenamento jurídico -, a absurda recalcitrância do trabalho escravo, do trabalho infantil, além da violência do narcotráfico rural, os crimes contra indígenas e contra o meio ambiente, e mesmo a violência proveniente da negligência estatal diante desse quadro social, quando o Estado "[...] por meio de seus poderes endossa com a morosidade, descumprimento legal de normas constitucionais e omissão" as situações de pobreza e violência (MANIGLIA, 2006, p. 3).

Leonilde de Medeiros (2002, p. 184), apoiando-se na tese de Maria Silvia Carvalho Franco, aponta a constatação da citada acadêmica de que a "[...] violência se constituiu no Brasil em uma forma rotinizada de ajustamento nas relações de vizinhança e institucionalizou-se como um padrão de comportamento". Em âmbito rural destaca-se a figura do latifundiário ou do capataz, acompanhado de jagunços, como forma de demonstração de força. Nesses contextos,

Se noções de justiça/injustiça se configuram entre os atingidos por estas práticas, na maior parte dos casos, não se desdobram em recursos a outras esferas de poder indicando que, do universo do trabalhador comum, muitas vezes, não faz parte a possibilidade de recurso à lei como instância mediadora das relações, nem muito menos a busca de espaços de discussão e negociação (MEDEIROS, 2002, p. 185$-186)$.

Medeiros (2002, p. 189) diagnostica que a modernização da agricultura não redundou na superação das antigas práticas violentas, e “[...] como o mundo dos direitos não chegou ao campo, foi mantido um amplo espaço social para a utilização do arbítrio e da força". Para agravar ainda mais esse quadro, há o comprometimento do Poder Judiciário com os interesses dos grandes proprietários de terra: 
Num contexto em que o uso da força torna-se uma face presente e naturalizada nas relações sociais e em que exclui-se a possibilidade de um recurso para fora da esfera dessas relações de mando, o comprometimento do Judiciário acaba por alimentar ainda mais as ações violentas, na medida em que socialmente se constrói uma expectativa de que não é possível resolver nenhuma pendência fora das regras tradicionais. Em outras palavras, a modernidade e o mundo da lei e do contrato não chegaram ao campo (MEDEIROS, 2002, p. 193, grifo nosso).

Não se pode falar em democracia no campo sem considerar esse aspecto violento do contexto rural. A reforma agrária, a partir da realidade rural descrita, somente se converterá em instrumento de democratização rural se atacar frontalmente a violência e a pobreza.

\section{A LUTA POLÍTICA NO CAMPO BRASILEIRO}

Maria da Glória Gohn (2006, p. 7) identifica uma mudança paradigmática na década de 1990 no que se refere à concepção de participação:

No contexto dos anos 1990, a participação passou a ser vista sob o prisma de um novo paradigma - como Participação Cidadã, baseada na universalização dos direitos sociais, na ampliação do conceito de cidadania e numa nova compreensão sobre o papel e o caráter do Estado. A participação passou a ser concebida como intervenção social periódica e planejada, ao longo de todo o circuito de formulação e implementação de uma política pública, porque as políticas públicas ganharam destaque e centralidade nas estratégias de desenvolvimento, transformação e mudança social. A sociedade civil não é o único ator social passível de inovação e dinamização dos canais de participação, mas a sociedade política, por meio das políticas públicas, também passa a ser objeto de atenção e análises.

Leonardo Avritzer (2008, p. 159), também nesse sentido, entende que a Constituição de 1988 " [...] mudou o padrão de cidadania existente no Brasil tanto na cidade quanto no campo", sendo ela responsável pela introdução de instrumentos para a universalização dos direitos sociais, bem como por lançar elementos centrais para a reforma agrária.

Ocorre que, no Brasil, principalmente na década de 1990, observou-se, por outro lado, o que Evelina Danigno (2004, p. 95) chamou de confluência perversa o projeto político democratizante - que vem desde as lutas pela redemocratização do país - e a implementação do projeto neoliberal. Verifica-se, de um lado, um processo democratizante, "[...] que se expressa na criação de espaços públicos e na crescente participação da sociedade civil nos processos de discussão e de tomada de decisão 
relacionados com as questões e políticas públicas", cujo marco formal foi a Constituição de 1988, e, de outro lado, a partir da eleição de Fernando Collor em 1989, “[...] há a emergência de um projeto de Estado mínimo que se isenta progressivamente de seu papel de garantidor de direitos, por meio do encolhimento de suas responsabilidades sociais e sua transferência para a sociedade civil", projeto este que correspondeu a um projeto global de alinhamento ao Consenso de Washington, cujas ideias embasaram os modelos de sociedades neoliberais.

A perversidade reside justamente no fato de que, mesmo apontando para direções opostas, ambos os projetos confluem para a necessidade de "[...] uma sociedade civil ativa e propositiva" (DAGNINO, 2004, p. 95-97). E disso advém a necessidade de se ter cautela com relação à exaltação desse novo paradigma participativo da ampliação da cidadania, pois esses conceitos podem fundamentar projetos com finalidades contrárias, ainda mais considerando a banalidade com que são usados atualmente.

Por isso é essencial tratar da participação política enquanto atuação coletiva do povo do campo sob o enfoque de uma ação identificada com a luta política empreendida na área rural brasileira.

No campo brasileiro há pouco espaço para o idealismo de uma participação cidadã. A história dos movimentos camponeses no Brasil sempre foi marcada pela luta, muitas vezes aberta e violenta, contra a ordem estabelecida:

Em razão do desafio representado por esses movimentos camponeses contra a ordem estabelecida é que José de Souza Martins afirma que "poucos sabem e se dão conta de que o campesinato brasileiro é a única classe social que, desde a proclamação da República, tem uma reiterada experiência direta de confronto militar com o Exército: em Canudos, no Contestado e, de outro modo, em Trombas e Formoso; ou, então, uma experiência de intervenção direta do Exército: na insurreição no Sudoeste do Paraná, no Nordeste, e mais recentemente nos conflitos camponeses no Araguaia-Tocantins" (COMPARATO, 2003, p. 48).

É notória a capacidade de revolta dessas populações oprimidas:

O fato de, até recentemente, as populações oprimidas do campo não terem tido os meios de se situar conscientemente no plano político e econômico, de modo a traçar uma estratégia para mudar a situação, não significa, contudo, que não tenham sido capazes de se revoltar contra as condições de vida precárias que eram obrigadas a suportar, mesmo que essa revolta tivesse de ser mediada por movimentos messiânicos ou experiências religiosas (COMPARATO, 2003, p. 46). 
A repressão violenta das manifestações de revolta dos camponeses é a resposta dada pelas classes dominantes, que souberam identificar nelas uma potencialidade para a transformação:

As classes dominantes, no entanto, nunca se enganaram quanto ao potencial revolucionário dessas ocasionais demonstrações de insatisfação, sempre apontando para o perigo de contaminação dos demais segmentos da sociedade. Essa talvez seja a explicação para o fato de os movimentos revoltosos no campo terem sempre sido combatidos com firmeza (COMPARATO, B. K., 2003, p. 46).

Dirige-se, segundo José de Souza Martins (1993, p. 32), a violência para solapar a capacidade organizativa e de expressão política da população rural, mantendo-se uma situação de duplicidade, situando-os fora do processo histórico. Por isso, há reação violenta quando ocorrem manifestações de luta do povo rural por seus direitos, já que

[...] ao ocupar terra ou se manter na terra, invadem também o espaço político do poder local, escapam da dominação pessoal e do medo ao potentado do lugar, violam as bases do poder", ou seja, em outras palavras, mexer na propriedade da terra significa mexer no poder econômico e político das oligarquias latifundiárias (MARTINS, 1993, p. 32, 91).

E a violência no campo não é dirigida apenas contra os que lutam pela terra e pela reforma, mas manifesta-se igualmente no cotidiano de trabalhadores rurais que se submetem a relações de exploração que correspondem ao "[...] tradicional modo de relacionamento entre trabalhadores e fazendeiros, baseado no poder pessoal destes últimos uma relação desigual de mando e obediência e não, em primeiro plano, uma relação contratual entre iguais" (MARTINS, 1994, p. 61).

A configuração assumida pelo campo brasileiro como lugar da opressão e da suspensão dos direitos e garantias fundamentais dificulta enormemente a construção da democracia. Ademais, as lutas empreendidas no campo são, muitas das vezes, lutas por direitos já consagrados formalmente, mas carentes de efetividade. Seja por terra, por reforma agrária, ou pela observância dos direitos trabalhistas, são todas lutas pela efetividade de direitos existentes. Os movimentos sociais do campo, por meio das mobilizações e das ocupações de terras, exigem nada mais que a imposição normativa da Constituição de 1988 ao Estado e à sociedade (SAUER, 2010a). Ou seja, os movimentos sociais rurais são atacados violentamente ao cobrarem o cumprimento da Constituição.

É notório o caráter político desses movimentos, sendo descabido, 
segundo José de Souza Martins (1993, p. 55) “[...] classificar como pré-políticos os movimentos sociais de populações com essas características e que vivem sob essas condições. Porque seus movimentos supostamente pré-políticos proclamam, justamente, a necessidade da política".

Ao dissertar sobre o Movimento dos Trabalhadores Rurais Sem Terra (MST), Bruno Konder Comparato (2003, p. 24) destaca seu caráter político:

Consideramos que o MST se constituiu como um ator político, pois se trata de um grupo capaz de influenciar a opinião pública e de obrigar o governo a adotar determinadas medidas que são de seu interesse. Com efeito, ao estabelecer a política agrária, o governo não pode deixar de considerar a reação deste grupo, sem correr o risco de ver o seu grau de popularidade afetado negativamente. [...]

A novidade está na articulação que foi feita a partir de táticas e elementos já conhecidos, e na habilidade política que o movimento tem demonstrado, ao fazer aliados em vários segmentos da sociedade civil. Trata-se de uma forma diferente de reivindicação social, ou, se preferirmos, de uma nova forma de atuação política.

O cientista político (COMPARATO, 2003, p. 214-215) confere a essa atuação uma tonalidade ainda mais forte ao afirmar que, contrariamente a uma suposta tradição de passividade do povo brasileiro, "[...] o MST consegue se organizar, ter força política, e desafia os poderes constituídos, não permitindo, em nenhum momento, que a sociedade brasileira se esqueça da existência de milhares de trabalhadores rurais que não têm terra para cultivar". E esses movimentos, enquanto sujeitos políticos, recolocam a relevância do meio rural na agenda política brasileira (SAUER, 2010a, p. 28).

Marcelo Dias Varella (2002, p. 162) também confere relevo à força política da atuação do MST, movimento capaz de pressionar consideravelmente os poderes constituídos:

[...] o Executivo se vê forçado a realizar um processo de Reforma Agrária para atender à demanda social; o Legislativo (onde o movimento agrário ganha adeptos a cada eleição) confecciona leis mais avançadas socialmente; e o Judiciário passa a entender o ordenamento jurídico positivo em favor de todo o tecido social, não de um número pequeno de indivíduos.

Maria da Glória Gohn também destaca o MST como ator político, pois " [...] atribui qualidade aos atores sociais que compõem suas bases ao inseri-los num plano que vai além da luta pelo acesso à terra, que é a luta pela democracia, pela igualdade, contra a exclusão" (GOHN, 2000, p. 114). A autora entende os movimentos sociais, em geral, como catalisadores das mudanças ocorridas na sociedade, compondo, desta feita, as lutas nacionais 
pelo poder, configurando-se como forças sociais e parte da luta mais geral pelo poder na sociedade civil e política.

Vale ressaltar a autorizada opinião de Stédile e Fernandes (2000, p. 35-36) acerca do caráter político do movimento:

O MST só conseguiu sobreviver porque conseguiu casar interesses particulares, corporativos, com os interesses de classe. [...].

[...] [O caráter político do movimento] sempre esteve presente, desde o início da organização. Tivemos a compreensão de que a luta pela terra, pela reforma agrária, apesar de ter uma base social camponesa, somente seria levada adiante se fizesse parte da luta de classes. Desde o começo sabíamos que não estávamos lutando contra um grileiro. Estávamos lutando contra uma classe, a dos latifundiários. Que não estávamos lutando apenas para aplicar o Estatuto da Terra, mas lutando contra um Estado burguês. Os nossos inimigos são os latifundiários e o Estado, que não democratiza as relações sociais no campo, não leva o desenvolvimento para o meio rural. Esse Estado está imbuído de interesses de classe. Acreditamos que o MST soube compreender e incorporar na sua ideologia, na sua doutrina, esse componente político.

Interessante destacar no posicionamento da liderança do MST que a luta se volta contra o Estado, que figura como um opositor aos interesses do movimento. A fala de Stédile é do ano 2000, e entende-se que desde então houve mudanças consideráveis ao menos na postura do Estado brasileiro com relação às causas sociais, mas salta aos olhos a necessidade que o movimento viu de se combater um tipo de Estado que em nada servia à causa dos militantes do campo. Estado este que, conforme apontado, não democratizou as relações sociais, nem promoveu o desenvolvimento rural, o que o torna opositor aos interesses populares.

Sabe-se, lado outro, que tal concepção desses movimentos como atores políticos nem sempre teve aceitação razoável na mídia e em alguns governos. Stédile e Fernandes (2000, p. 36) também se manifestam sobre essa incompreensão:

Evidentemente que muita gente, tanto pela direita quanto pela esquerda, não consegue fazer uma interpretação correta desse caráter político do movimento. Simplificam com facilidade o componente político como se fosse apenas uma vocação partidária. Em vários momentos da nossa história houve quem afirmasse que o MST iria se tornar um partido político. Nunca esteve no horizonte do MST se transformar em partido político. Mas também nunca abrimos mão de participar da vida política do país.

Stédile e Fernandes (2000, p. 50) consignam, ainda, que foi o MST que cristalizou a necessidade da luta de massas: 
Esse negócio de assembleia, de abaixo-assinado para o governo, de audiência, isso não resolve", era o que pensávamos. Poderia até ser um aprendizado pedagógico para as massas, mas se não houvesse luta de massas a reforma agrária não avançaria. Tínhamos seis anos de luta e se havia dado certo até aquele momento era porque o povo havia se envolvido. Essa era a nossa experiência.

José Carlos Garcia (2000, p. 171) interpreta a atuação do MST como um ato de desobediência civil:

Daí ser possível dizer que as ocupações e manifestações do MST são tendencialmente não-violentas, ou que a violência é utilizada no mais das vezes de forma reativa e com meios extremamente moderados, se comparados aos empregados pelos agressores. [...] é possível caracterizar-se a atuação ordinária do MST como prática de atos de desobediência civil, com o que seria legitimada sua presença no cenário nacional em conformidade com o Estado Democrático de Direito e as modernas concepções de democracia.

Isso leva, segundo o autor, à compreensão da desobediência como elemento que integra o Estado Democrático de Direito, o que significa defender a luta pela formação de uma cultura democrática e de uma compreensão da Constituição enquanto algo aberto, como projeto inacabado (GARCIA, 2000, p. 172). Essa compreensão da Constituição como projeto aberto e inacabado, casa-se com a relevância do MST e de outros movimentos sociais rurais, em representarem intérpretes desse texto constitucional na luta pelos direitos nele consagrados.

Garcia (2000, p. 172) relaciona, ainda, a atuação do MST e sua importância para a consolidação democrática:

Somente o fortalecimento da sociedade civil e da cidadania ativa podem sustentar uma noção democrática de governabilidade em tempos de incerteza e transição como os atuais. A incorporação de sujeitos coletivos como o MST e o reconhecimento de sua importância na consolidação democrática, portanto, inserem-se no esforço de resistência às teses de governabilidade neoliberal e de composição de um leque mais amplo de contrapoderes que ofensivamente construam um paradigma diferente de prática política e relação entre o Estado, o mercado e a sociedade civil.

Sobre a luta no campo, Sérgio Sauer aponta que alguns autores demonstraram que estas transcendem a demanda por terra, constituindo-se como luta por libertação e emancipação. São lutas por sobrevivência, mas que não se restringem à dimensão econômica, albergando demandas como saúde, educação e justiça, entre outras, e que possibilitam processos sociais e políticos de recriação do campo e de uma nova ruralidade. São lutas contra a exclusão política, contra a marginalização social, lutas eminentemente políticas não só por terra, mas por cidadania e democracia. O que está em curso, para o autor, 
é um processo social de reinvenção do campo materializado pela luta pela terra, que ao agregar novos elementos e perspectivas acaba por criar uma nova ruralidade (SAUER, 2010a, p. 36-37).

Nesse processo, a democratização do acesso à terra figura como elemento central:

[...] a democratização do acesso à propriedade terra - mais do que uma simples política social compensatória de combate à pobreza rural - representa a possibilidade da construção de identidades e cidadania no meio rural", luta esta que se vincula à busca de um lugar de oportunidades e autodeterminação, diferente do espaço urbano (SAUER, 2010a, p. 36-37).

Sauer (2010b, p. 43) vincula a luta dos sem-terra à ideia das heterotopias elaborada por Michel Foucault, que representa na realidade rural do país, a construção de um "[...] outro lugar qualitativamente diferente e de resistência ao processo de territorialização, forçada pelo modelo agrário e agropecuário implantado no Brasil". Para elucidar melhor o conceito foucaultiano, o autor relaciona-o com algo como a existência de contralugares na sociedade atual, que servem de lócus de contestação do espaço em que se vive. Nas palavras de Sauer (2010a, p. 66, 69-70), “[...] são espaços singulares que se contrapõem à dominação e à homogeneidade espacial. Lugares de resistência e liberdade, construídos a partir de perspectivas e relações sociais diferentes da dominação hegemônica do capital ou de valores culturais impostos". A heterotopia surge como a possibilidade não de se inventar lugar totalmente outro, ou um não lugar, mas de ocasionar uma mudança de perspectiva do centro para as margens, com a luta por alternativas sendo travada a partir dos excluídos e marginalizados pelo sistema econômico.

Os acampamentos e, posteriormente, os assentamentos, podem ser espaços de reinvenção social, compostos por "[...] diferentes biografias na busca de um lugar de vida, trabalho e cidadania" (SAUER, 2010b, p. 38), sendo as experiências de luta e de acesso à terra, impulsionadoras de mudanças culturais e simbólicas num processo que gera novos valores e representações sociais, inovando as perspectivas em âmbito rural.

Esse processo pode ser identificado por meio da análise de algumas experiências de assentados. Fabiana Severi (2012, p. 161-162), em pesquisa empírica, levantou algumas das mudanças advindas da luta por meio de entrevistas realizadas com alguns assentados, sendo apontada a construção de uma visão mais complexa da política, de uma percepção melhor sobre os direitos com a aquisição de voz ativa nas reivindicações, e 
sobre a condição dos assentados como sujeitos de direito, a autora também constatou maior igualdade entre homens e mulheres, o sentimento de pertencimento a uma coletividade, entre outros fatores.

Segundo Severi (2012, p. 164) houve, além da manifestação de variadas formas de sociabilidade e solidariedade, a experimentação do espaço público como lugar da reivindicação por direitos, espaço este que perdeu seu caráter privado para ganhar densidade política, já que foi ocupado por sujeitos que lutam por direitos, e não apenas pela propriedade.

Severi (2012, p. 185) exemplifica essa mudança substancial na compreensão dos trabalhadores rurais no que concerne à posição que devem ocupar enquanto sujeitos de direito:

Já se mobilizaram no assentamento para a conquista de direitos que consideravam importantes. Na Prefeitura de Serra Azul exigiram a passagem do caminhão de lixo e a ligação de energia elétrica, não por meio de formas clientelísticas tradicionais, mas dentro das regras do jogo democrático e pela compreensão desses bens como direitos e não favores a serem oferecidos pelo governo.

Cléria Botelho da Costa (2002, p. 151, grifo do autor) também destaca o fato de que os trabalhadores rurais não se satisfazem com a conquista da terra, reivindicando melhores condições de trabalho e de produção, e uma sociedade mais igualitária:

A experiência histórica do MST mostra que mesmo depois que o Estado (via Incra) realiza a imissão das terras que ocupam, os sem-terra confirmam que a luta não se encerra, como se vê nos relatos de trabalhadores: nós quer agora que o prefeito arrume escola para os nossos filhos estudar; ou: nós quer que o prefeito arrume estrada pra nossa produção sair daqui.

Costa (2002) entende que estas e outras narrativas revelam que a cidadania para os componentes do MST não se restringe aos direitos instituídos, como o direito à terra, indo além na busca por direitos que eles vislumbraram no próprio processo de luta, incorporando direitos cuja prática cotidiana confere importância. E isso significa que o MST vai além do conceito liberal de cidadania, levando a luta para além dos direitos vinculados a esse paradigma.

Severi (2012) concluiu que tanto entre acampados quanto entre assentados há uma confrontação com o conteúdo ideológico do discurso da neutralidade da lei moderna. As divergências e ambiguidades existentes entre as orientações dos órgãos do Estado, e essa postura possibilitou que se ampliasse o sentido geral de alguns direitos fundamentais que são apenas formalmente garantidos nas atuais democracias. Muda-se, desse modo, a 
percepção que se tem dos direitos e do Estado por meio da práxis política.

As lutas operam uma mudança até mesmo na linguagem dos envolvidos, com a apropriação de conteúdos políticos, que procedem da própria luta por libertação e das relações vividas nos espaços de sociabilidade a que pertencem (acampamentos e assentamentos) (SEVERI, 2012). Há o abandono da “[...] fala enquanto conjunto de frases soltas" e passa-se a elaborar uma linguagem política, através da qual as carências sofridas podem ser "ressignificadas em termos de direitos e garantias" (SEVERI, 2012, p. 191).

Entende-se que uma concepção adequada de democracia (diferente da democracia liberal em voga) se coaduna com a tentativa de se manter essa linguagem política adquirida na luta social, luta esta que pode se insinuar criativamente no modelo de democracia aberta, fazendo com que a transformação da realidade se dê pelo exercício do poder soberano pelo povo do campo.

O regime democrático que se abre à criatividade e à vontade popular, e que deve ter a abertura institucional necessária para viabilizar a transformação dos desejos do povo em direitos e garantias, em políticas públicas que viabilizam a realização destes mesmos direitos, parece ser o regime adequado à continuidade das lutas sociais e à consequente formação de uma cultura democrática que não permita o arrefecimento da participação para a contínua expansão dos direitos, a contínua reorientação do Estado Democrático na mudança social.

\section{A CONTINUIDADE DA LUTA}

Entretanto, deve-se levar em conta que é real o risco da perda dessa linguagem política adquirida, pois "[...] em longo prazo, a força dos mecanismos de integração e de dessensibilização, próprios das sociedades administradas, atuarão brutalmente em favor do esquecimento da linguagem conquistada" (SEVERI, 2012, p. 193-194).

O antídoto contra a perda da militância poderia ser, na opinião de Severi (2012, p. 193), “[...] o exercício permanente e vivo da linguagem nos espaços coletivos do assentamento e nos espaços fora do assentamento de maneira coletiva”, o que pede, necessariamente, que a construção de uma cultura radicalmente democrática receba incentivos permanentes para sua propagação.

Um conceito substancial de reforma agrária (POSSAS, 2014) vem a calhar no sentido de firmar no horizonte da luta política que o assentamento 
é uma importante conquista, mas não consiste no ponto de chegada de toda a mobilização. A viabilização do assentamento pede uma grande variedade de políticas públicas que conferirão materialidade aos ideais dos assentados, e passarão a compor todo o quadro da reforma. E aí a luta ganha continuidade, justamente no que tange às decisões acerca dessas políticas que comporão a reforma agrária. A luta continua na direção da superação do paradigma vigente, qual seja, de se estabelecerem planos de reforma verticalmente, ao sabor das elites políticas, e sem a consideração dos anseios populares.

Sérgio Sauer (2010a, p. 94) traz uma interessante diferenciação entre luta pela terra e reforma agrária. Diz o autor que é "[...] importante ter claro que a reforma agrária é, por excelência, uma política de Estado. Diferentemente da luta pela terra (uma ação popular), o próprio conceito de reforma agrária está ligado ao papel e às responsabilidades do Estado". Essa diferenciação é clara, facilmente assimilável, mas carece de um complemento necessário: reforma e luta pela terra devem estar imbricadas para a configuração da democracia, mormente no que toca ao âmbito rural brasileiro, obviamente, mas tendo direta implicação no país como um todo.

O próprio Sauer (2010a, p. 96) destaca esse aspecto e a necessidade dessa aproximação:

[...] a reforma agrária - muito além de uma política pública implementada apenas para cumprir o direito de acesso à terra - deve ser conjugada com a luta pela terra (mobilização social) como uma ação autônoma de plena participação que, consequentemente, permite às pessoas serem sujeitas de sua própria história.

E os movimentos sociais rurais exercem primordial papel para essa imbricação quando se fazem presentes na arena pública e resgatam o protagonismo popular por meio da soberania do povo, e atuam na demarcação das políticas públicas (atuação cidadã). Além de cobrarem a efetivação dos direitos fundamentais dos habitantes do campo, direitos estes sistematicamente desrespeitados, essa atuação revitaliza o conceito de democracia com o resgate de dois de seus pressupostos essenciais: a soberania popular e a observância dos direitos humanos (SAUER, 2010a, p. 122-123). Por outro lado, essa tomada de consciência representa a continuidade da luta que não se encerra com o assentamento. A luta política adquire um novo patamar, envolve novos direitos e demandas, mas a participação persiste na construção social da nova realidade. A continuidade da luta implica a definição das políticas públicas subsequentes, responsáveis pela viabilização dos assentamentos. E vai muito além. 


\section{CONCLUSÃO}

"Os brotos de dor e de revolta cresciam naquela seara vermelha de sangue e fome, era chegado o tempo da colheita". Jorge Amado (1987, p. 335).

O presente texto defende o resgate da soberania popular como pilar central da democracia contemporânea. É pertinente para essa finalidade, sobretudo quando a reflexão se dirige ao campo brasileiro, a formulação consagrada por Fábio Konder Comparato (1989), que aponta a necessidade de se pensar na soberania como uma soberania dos pobres. O jurista afirma a necessidade de se partir da distinção levada a cabo por Aristóteles entre democracia e oligarquia, a primeira sendo o governo dos pobres, enquanto a segunda é capitaneada pelos abastados, e optar abertamente pela soberania dos pobres.

Comparato alega duas razões que fundamentam essa escolha: de um lado, tem-se que os excluídos, aqueles que não possuem propriedade e poder econômico, são os maiores interessados no estabelecimento de um regime igualitário, no qual a igualdade se faça presente no acesso ao poder, à cultura, ao lazer, à produção, ao consumo e exerça o subversivo papel de transformação da sociedade. Em segundo lugar, levando-se em conta que a população pobre representa a efetiva maioria da população em geral, nada mais justo que atribuir a esse contingente um protagonismo soberano. Para além de qualquer redução idealista, essa soberania deverá implicar, ainda, a possibilidade de intervenção direta nos mecanismos de funcionamento do Estado. Não é suficiente a consagração desse princípio sem que se organize a sociedade para efetivamente exercer esse poder (COMPARATO, 1989).

Essa perspectiva de alteração da dinâmica do poder, mormente em sua manifestação em âmbito rural, em que latifundiários e o Estado vilipendiam os camponeses em seus direitos fundamentais, é o aspecto central desenvolvido no presente trabalho. Esta redistribuição do poder só poderá ser realizada com o exercício do poder soberano pelos excluídos e pelos explorados.

Portanto, a ideia de soberania dos pobres ganha toda a pertinência quando pensada para o contexto rural. É apenas se fazendo presente, soberanamente, na esfera pública que esse contingente explorado conseguirá 
fazer que seus direitos previstos, e outros ainda não formalizados, tenham efetividade social.

Aqui não se trata mais de fazer pressão, apenas, como comumente defendido por autores do espectro liberal. A pressão é de extrema relevância, sem dúvida. Sem a atuação do MST, por exemplo, a questão agrária com seu déficit de democracia no campo estaria em situação ainda mais deplorável. Mas a questão passa, para além da pressão, em lutar por uma democracia material, marcada pela abertura, pela mutabilidade, pelo contínuo reinventar-se enquanto regime, enquanto sociedade democrática (como na teorização de Claude Lefort, 2011). Essa indomesticabilidade, no sentido lefortiano, seria algo positivo na configuração de novas realidades. E quem figuraria na ponta dessa sociedade que se reinventa, que rompe a clausura para realizar a revolução democrática, e que ataca frontalmente suas mazelas mais grotescas, como a pobreza, só pode ser o povo. Povo este que no campo, conforme demonstrado, traz uma herança antiga de lutas e resistências à violência, ao descaso, à omissão.

Slavoj Zizek (2008) aponta expressamente que a tarefa primordial do século XXI é politizar o seguimento de excluídos. Ele se refere especificamente aos que vivem nas favelas, mas a ideia é plenamente aplicável aos excluídos que habitam o rural:

Se a principal tarefa da política emancipatória do século 19 foi romper o monopólio dos liberais burgueses por meio da politização da classe trabalhadora, e se a tarefa do século 20 foi despertar politicamente a imensa população rural da Ásia e da África, a principal tarefa do século 21 é politizar - organizar e disciplinar - as "massas desestruturadas" dos que vivem nas favelas. Se ignorarmos esse problema dos excluídos, todos os outros antagonismos perdem seu viés subversivo.

Os trabalhadores do campo contam com movimentos sociais diversos que podem levar a cabo essa tarefa de politização. Conforme argumentado acima, o MST já realiza de forma satisfatória esse papel junto aos trabalhadores rurais, e a perspectiva é que essa luta continue mesmo depois de atingida a etapa de conquista do assentamento. Toda organização, politização e histórico de luta dos movimentos do campo são fatores primaciais para a luta popular no campo.

Em síntese, a luta contra o poder da terra é uma luta por democracia, contra a opressão, contra a exploração, pelo respeito aos direitos fundamentais e pelo protagonismo político do povo. As demandas todas se encaixam perfeitamente no espectro democrático que a democracia comporta, nunca é demais repetir, também o alargamento dos limites 
do possível. Somente por meio dessa luta democrática é que se poderá solucionar a questão agrária.

\section{REFERÊNCIAS}

ABRAMOVAY, R.; MORELLO, T. A democracia na raiz das novas dinâmicas rurais brasileiras. Brasília: IICA, 2010. Disponível em: http:// www.rimisp.org/wp-content/uploads/2010/05/Paper-Country-OverviewBrazil-1.pdf. Acesso em: 12 nov. 2019.

ABRAMOVAY, R. O futuro das regiões rurais. Porto Alegre: UFRGS, 2009.

AMADO, J. Seara vermelha. 46. ed. São Paulo: Record, 1987.

AVRITZER, L. Terra e cidadania no Brasil. In: STARLING, H. M. M.; RODRIGUES, H. E.; TELLES, M. (org.). Utopias agrárias. Belo Horizonte: UFMG, p. 150-166. 2008.

DAGNINO, E. Sociedade civil, participação e cidadania: de que estamos falando? In: MATO, D. (coord.). Políticas de ciudadanía y sociedad civil en tiempos de globalización. Caracas: FACES, 2004. p. 95-110.

COMPARATO, F. K. Para viver a democracia. São Paulo: Brasiliense, 1989.

COMPARATO, F. K. Direitos e deveres fundamentais em matéria de propriedade. Revista CJF, Brasília, DF, v. 1, n. 3, p. 92-99, set./dez. 1997. Disponível em: http://www.dhnet.org.br/direitos/militantes/comparato/comparato_direitos_deveres_fundamentais_materia_propriedade.pdf. Acesso em: 12 nov. 2019.

COMPARATO, B. K. A ação política do MST. São Paulo: Expressão Popular, 2003.

COSTA, C. B. Terra: representações e cidadania. In: SOUSA JUNIOR, J. G. (org.). Introdução crítica ao direito agrário. Brasília, DF: UnB, 2002. p. $146-152$.

GARCIA, J. C. O MST entre a desobediência civil e democracia. In: STROZAKE, J. J. (org.). A questão agrária e a justiça. São Paulo: Revista dos Tribunais, 2000. p. 15-87.

GOHN, M. G. Os sem-terra, ONG's e cidadania. São Paulo: Cortez, 2000. 
GOHN, M. G. Conselhos gestores e gestão pública. Ciências Sociais Unisinos, São Leopoldo, v. 42, n. 1, p. 5-11, jan./abr. 2006.

LEFORT, C. A invenção democrática: os limites da dominação totalitária. Belo Horizonte: Autêntica, 2011.

MANIGLIA, E. Direito agrário e cidadania: construindo a democracia no campo. Revista de Estudos Jurídicos da Universidade Estadual Paulista, Franca, v. 11, n. 7, p. 163-172, 2002. Disponível em: http:/www.abda. com.br/texto/ElizabeteManiglia2.pdf. Acesso em: 12 nov. 2019.

MANIGLIA, E. Criminalidade e violência no âmbito rural: críticas e reflexões. In: MANIGLIA, E.; BARROSO, L. A.; MIRANDA, A. G. (org.). A nova lei agrária. Curitiba: Juruá, 2006. p. 179-192. (Biblioteca Científica de Direito Agrário, Agroambiental, Agroalimentar e do Agronegócio, v. 1).

MARTINS, J. S. A chegada do estranho. São Paulo: Hucitec, 1993.

MARTINS, J. S. O poder do atraso: ensaios de sociologia da história lenta. São Paulo: Hucitec, 1994.

MEDEIROS, L. S. Dimensões políticas da violência no campo. In: SOUSA JUNIOR, J. G. (org.). Introdução crítica ao direito agrário. Brasília, DF: UnB, 2002. p. 181-195.

POSSAS, T. L.; MANIGLIA, E. Estado e violência: sobre a ausência de políticas públicas. In: MANIGLIA, E. (org.). Direito, políticas públicas e sustentabilidade: temas atuais. São Paulo: Cultura Acadêmica, 2011. p. 11-18.

POSSAS, T. L. Reforma Agrária Brasileira: elementos para um conceito substantivo. In: MANIGLIA, E. (org.). 50 anos do Estatuto da Terra e 25 anos de Direito Agrário na Unesp. São Paulo: Cultura Acadêmica, 2014. p. 307-322.

SAUER, S. Terra e modernidade: a reinvenção do campo brasileiro. São Paulo: Expressão Popular, 2010a.

SAUER, S. Reforma agrária de mercado no Brasil: um sonho que se tornou dívida. Estudos Sociedade e Agricultura, Rio de Janeiro, v. 18, n. 1, p. 98$-126,2010 b$.

SEVERI, F. Da lona ao roçado: memórias e experiências de moradores de um assentamento de reforma agrária. São Paulo: Annablume, 2012. 
STARLING, H. M. M.; RODRIGUES, H. E.; TELLES, M. Utopias agrárias. Belo Horizonte: UFMG, 2008.

STÉDILE, J. P.; FERNANDES, B. M. Brava gente: a trajetória do MST e a luta pela terra no Brasil. São Paulo: Fundação Perseu Abramo, 2000.

VARELLA, M. D. O MST e o Direito. In: SOUSA JUNIOR, J. G. (org.). Introdução crítica ao direito agrário. Brasília, DF: UnB, 2002. p. 153-163. ZIZEK, S. Missão: impossível. Folha de S. Paulo, São Paulo, 4 maio 2008. Caderno Mais! Disponível em: https://wwwl.folha.uol.com.br/fsp/mais/ fs0405200816.htm. Acesso em: 12 nov. 2019.

Artigo recebido em: 09/05/2019.

Artigo aceito em: 30/10/2019.

\section{Como citar este artigo (ABNT):}

POSSAS, T. L. A democracia e a luta político-jurídica no campo brasileiro. Veredas do Direito, Belo Horizonte, v. 16, n. 36, p. 171-190, set/dez. 2019. Disponível em: http://www.domhelder.edu.br/revista/index.php/veredas/ article/view/1536. Acesso em: dia mês. ano. 